REVIEW ARTICLE

\title{
TISSUE ENGINEERING AND REGENERATIVE MEDICINE: A REVIEW
}

\author{
Aditya Wardhana ${ }^{1}, \&$ Michelle Valeria ${ }^{2}$
}

1. Burns Section, Division of Plastic Surgery, Faculty of Medicine Universitas Indonesia, dr. Cipto Mangunkusumo National Hospital, Jakarta, Indonesia.

2. Faculty of Medicine, Universitas Indonesia, Jakarta, Indonesia.

\begin{abstract}
Summary: The concept of tissue engineering has now been accounted for one of the most prospective answers to the growing needs of tissue and organ replacements. Many studies and researches are continuously done to achieve a paramount strategy in tissue engineering and regenerative medicine. This review emphasizes the concept, strategies, current application, and current challenges in tissue engineering. The strategy in tissue engineering has much improved and successfully applied in several reconstructive cases. Understanding of isolated cells behaviours, materials suitable for it's scaffolds, in adjuncts with specific growth-inducing factors for each specific tissue or organ built is the key for successful tissue engineering.

Keywords: Tissue Engineering; Regenerative Medicine; Plastic Surgery

Ringkasan: Konsep tissue engineering merupakan salah satu jawaban yang paling diharapkan dapat memenuhi kebutuhan pengganti jaringan dan organ yang terus meningkat pada saat ini. Beragam studi dan penelitian secara terus-menerus dilakukan agar dapat memperoleh strategi terbaik dalam tissue engineering dan regenerative medicine. Artikel ini berfokus pada konsep, strategi, aplikasi terkini, dan tantangan di masa mendatang pada tissue engineering. Strategi tissue engineering telah banyak berkembangan dan berhasil diterapkan pada kasus-kasus rekonstruksi. Pemahaman mengenai perilaku sel, kecocokan material dengan scaffolds, serta faktor pendukung pertumbuhan untuk masing-masing jaringan atau organ spesifik yang akan diciptakan merupakan kunci keberhasian tissue engineering

Kata Kunci: Teknik Jaringan; Kedokteran Regeneratif; Bedah Plastik
\end{abstract}

\section{Conflicts of Interest Statement:}

The author(s) listed in this manuscript declare the absence of any conflict of interest on the subject matter or materials discussed. 


\section{TISSUE ENGINEERING AND REGENERATIVE MEDICINE}

The concept of tissue engineering was first defined by Langer and Vacanti as an interdisciplinary field that applies engineering and life sciences principles in developing biological tissue that preserves, protects, and enhances its proper functions., ${ }^{1,2,3}$ Tissue engineering and regenerative medicine are two terms that often used as interchangeable terms, even if it is different. Tissue engineering focuses on creating and forming biological substitutes to reform functioning tissues or organs based on principles mentioned before. ${ }^{4,5}$ While regenerative medicine focuses on utilizing cells' natural regenerative qualities (by directly forming tissue or indirectly releasing factors that can induce endogenous tissue healing) to reform damaged cells. Both tissue engineering and regenerative medicine work in conjunction as a strategy to recreate functioning organs or tissues. ${ }^{5}$

\section{HISTORICAL PERSPECTIVE OF TISSUE ENGINEERING AND REGENERATIVE MEDICINE}

Attempts to adapt tissue engineering and regenerative medicine strategies started back in $1500 \mathrm{BC}$. This initial trial utilized wood to replace body parts' mechanical properties for nasal reconstruction. ${ }^{5}$ This first attempt with nonprosthetic devices (woods, metals) can be perceived as biomaterials adaptation in reconstructive medicine. Similar adaptation was also seen during Galileo-Roman period, when dental implant was done for teeth replacement. It was continued until the $18^{\text {th }}$ century when replacing teeth with homologous (human) transplant was recognized as a common practice. ${ }^{6}$

Alongside the growth and more understanding of tissue replacement practice, clinical application of tissue-based therapies using skin grafts was founded. Autologous skin grafting was first successfully done by Heinrich Christian Bunger then followed by Jaques Reverdin (1842-1929) and Karl Thriesch (18271895) in Europe. 6,7

Rudolf Virchow laid out his concept of tissue transplantation through his work, known as Cellularpathologie. He described that regeneration of tissue depends on cell proliferation. This concept led to further researches on cellular effect of tissue healing and studies on cultivation of cells in vitro by C.A. Ljunggren, J. Joly, and RG Harrison. Ever since, in vitro cell culture became the standard procedure for tissue engineering. 6

First reported skin substitutes were documented in 1962 by Chardack using Ivalon sponge. In 1975, Howard Green and colleagues showed in vitro cultivation of keratinocytes started by hervesting keratinocytes isolated from human skin biopsy with mouse mesenchymal cells to grow skin epidermis. This research led to first cultured autologous epithelium product, which later was commercialized as Epicel by Genzyme in 1979. Other early skin substitute product was developed by Burke and Yannas, known as Dermal Regeneration Template by Integra Life Sciences. It was widely used for treating burns wounds. Then only by 1987, the term "tissue engineering" was properly defined by Langer and Vacanti. The same definition is still used up until nowadays. 6,7

While as Regenerative Medicine was not defined until recently perceived as a field that focuses on inducing cells' regenerative qualities which is beneficial for engineering cells or tissues. As defined by that concept, the development of regenerative medicine fluctuates on stem cells utilization. Stem cells, with plasticity and cloning capacity, are modulated to form differentiated cells. Robert Briggs and Thomas king first showed cloning concepts on frogs. One of the most well-known mammalian cloning was done by Ian Wilmut and colleagues which is cloning of the sheep Dolly. For the past decade, the ethical issue is the major problem faced in the development and application of regenerative medicine. ${ }^{6}$

The development of tissue engineering and regenerative medicine is also evident in Indonesia. Few Stem Cell Units have been established in Indonesia with a total of eleven eligible hospitals in administering stem cell based researches based on Kepmenkes no 32 tahun 2014. ${ }^{8}$ RSUP dr. Cipto Mangunkusumo-Fakultas Kedokteran Universitas Indonesia (RSCM-FKUI) as one of the eligible party, had established the Stem Cell Medical Technology Integrated Service Unit and started the first attempt to culture mesenchymal stem cells back in $2009 .{ }^{9}$

\section{STRATEGIES IN TISSUE ENGINEERING AND REGENERATIVE MEDICINE}


Current main strategies in tissue engineering and regenerative medicine are injection of isolated or cultured cells, in situ tissue regeneration, and cell-material hybrids. Following studies and researches, it is later known that injection of isolated or cultured cell source does not guarantee accurate localization of all injected cells to target damaged organs and possible consequences from remaining injected cells in the body. There are also unknown whole tissue restoration abilities as injected cells only with no inducing substances and materials may not differentiate into well-functioning tissues. With this strategy, studies report failures in implantation of the scaffold that has been implanted with cells in situ. These occur because of the insufficient microvascular networks, therefore resulting in the absence of adequate oxygen diffusion to the scaffold and cells implanted into the organ defect. ${ }^{5}$

The latest tissue engineering strategy, known as a cell-material hybrid, consists of isolated cells and biomaterial scaffold with or without some tissue inducing substances (usually growth hormones). ${ }^{1}$

\section{ISOLATED CELLS}

Cells isolated from sources, such as fully differentiated somatic cell lines or stem cells. Fully differentiated somatic cell lines are terminally differentiated cells that can produce desired phenotypes, but reviews show its difficulty in balancing the proliferation and differentiation qualities. These terminally differentiated cells are harder to culture ex vivo compared to stem cells. Stem cells serve as pluripotent cells with the ability to differentiate into mature cells. Proliferate to conduct a selfrenewal ability and adjustable immune tolerance. These stem cells are harvested from embryonic and adult tissues (bone marrows, skin, liver, adipose tissue, brain, and others). 5,10

Adult stem cells or human mesenchymal stem cells (hMSCs) are usually harvested from bone marrow and adipose tissues. hMSCs allow its usage for all strategies of tissue engineering; injectable cell therapies, in situ tissue regeneration, and cell-material hybrid. Although known for its possession of multipotency and self-renewing ability, its differentiation potentials are limited for mesodermal derived tissues (unable to form ectodermal nor endodermal derived tissues). Embryonic stem cells are extracted from human embryonic tissue and have the ability of self-renew and differentiate into endodermal, mesodermal, and ectodermal tissues. Some in vitro demonstrations show its usage on producing neurons, hepatocytes, skin, cardiac and skeletal muscle cells, adipocytes, chondrocytes, and osteoblasts, pancreatic cells, and hematopoietic cells. Despite its leading capabilities compared to other cells, human embryonic stem cells (hESCs) are present with ethical concerns and risk of tumorigenesis in its application. ${ }^{5}$ Other tissue-specific stem cells have been identified in skin, heart, muscle, brain and can be isolated for tissue regeneration. ${ }^{10}$

\section{SCAFFOLD}

A Scaffold is a three-dimensional extracellular construct as the mediator between isolated cultured cells and target organ defects. A scaffold has to be degradable and resorbable so the native cell/implanted tissue will be the only thing remaining on the defect after implantation. A matrix can be constructed from synthetic or natural material with autologous, allogenous, or xenogenous sources. Natural matrices, such as hyaluronic acid and collagen can be used or substituted with synthetic matrices, such as polymeric and hydrogel scaffolds. Other enhancements in the creation of scaffolds include microfabrication, microprinting, computer modeling, and nanotechnology that enables modulation and enhances cells-matrix interaction that further benefit tissue engineering processes.., 10

\section{TISSUE ENGGINEERING SUBSTANCES}

Tissue-inducing substances are commonly growth factors that are used supplementary to enhance the regeneration process. Specific growth factors can be tailored for each type of cells and their functions; such as using TGF- $\beta$ for scar healing. Some other growth factors that are commonly used are fibroblast growth factor and epidermal growth factor. Various substances with different doses, concentrations, and mechanisms of action can be utilized with consideration of safety and interaction between cells, scaffold, and added substances itself. ${ }^{10}$ 


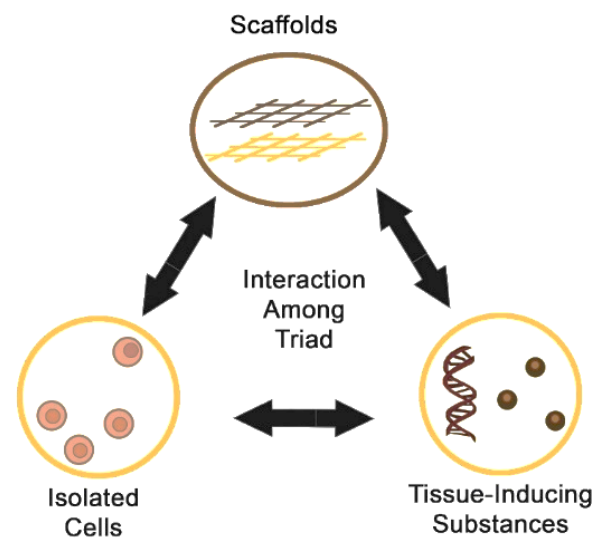

Figure 1. Components in Tissue Engineering1. Main components of tissue engineering are isolated cells, scaffolds, and tissue-inducing substances. Results in functional, aesthetic, survival qualities obtained can waidely varies even with a slight change in products' composition. Aside from complete understanding of each component of the triad (various available option of cells, types of scaffold, characteristic, doses, mechanism of action of inducing factors), it is essential to form a proper interaction in between appropriate components to achieve desired outcome.

\section{APPLICATION OF TISSUE ENGINEERING AND REGENERATIVE MEDICINE}

Plastic surgery manipulates materials and tissues for reconstructive strategies whereas tissue engineering focuses on the creation of biological substitutes to reform damaged tissues or organs. ${ }^{10}$ Application of tissue engineering and regenerative medicine strategies as a part of plastic surgery practice is therefore very likely in the near future.

Adaption of tissue engineering has been widely discussed and tested. Skin, fat, bone, and cartilage are among the most researched and tested target tissue for various reasons.

\section{SKIN TISSUE ENGINEERING}

Skin Tissue Engineering's superiority in treating wounds is its minimal donor tissue needed for the same area closure compared to traditional autografts or flaps. It is suitable for minimizing short- and long-term complications in donor sites that often occur post skin reconstructions. Researches on skin tissue engineering started by Rheinwald and Green in 1974 by creating cultured epithelial autografts (CEA). Keratinocytes were the targeted cells that were expanded and cultured for a few weeks in a proper matrix from a skin biopsy. In 1981, O' Conner and Gallico pioneered the direct application of CEA in treating skin defects on burn patients. Other groups also tried using CEA but were hindered by several problems; the frailty of the final cultured skin product, difficult handling, and unpredictable tissue uptake at recipient sites. Up until today, technologies have improved and several scaffolds and growth factors are used in the principle of skin engineering. Nowadays, skin engineering has been adapted in treating cases of full-thickness burns, chronic wounds, post-cancer reconstructions, and many more. Most recent adopted tissue engineering and regenerative medicine approaches are varied. Based on materials constructing the matrices, it is divided into cellular/natural and acellular/synthetic. ${ }^{1}$

Acellular skin substitutes usage started from the 1970s, mainly as a temporary closure for superficial to mid-dermal skin defect. ${ }^{9}$ Commonly used acellular/synthetic skin substitute products are Biobrane $^{\circledR}$, Integra ${ }^{\circledR}$, Hyalomatrix $^{\circledR}$, Alloderm ${ }^{\circledR} ., 12$ These products use the combination of natural and synthetic materials, such as collagen with silicon sheaths, fibrin, decellularized matrices, and work by giving temporary coverage, optimizing microenvironment, and therefore promoting endogenous wound healing. A meta-analysis comparing acellular skin substitutes to standard wound care treatment showed superior performance of skin substitutes on epithelialization rate, length of hospital stay, and pan management for treating pediatrics partial 

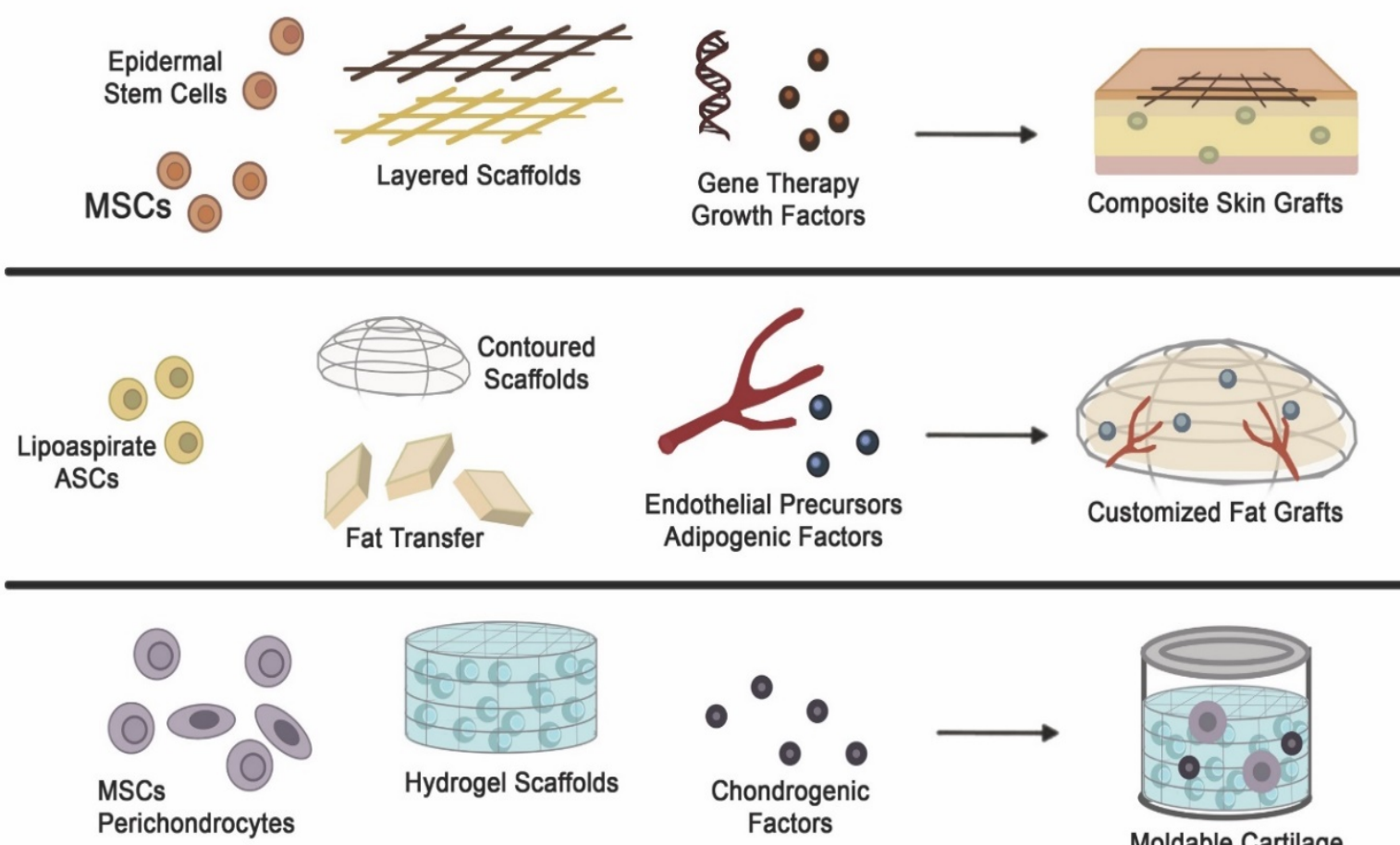

Hydrogel Scaffolds

Perichondrocytes
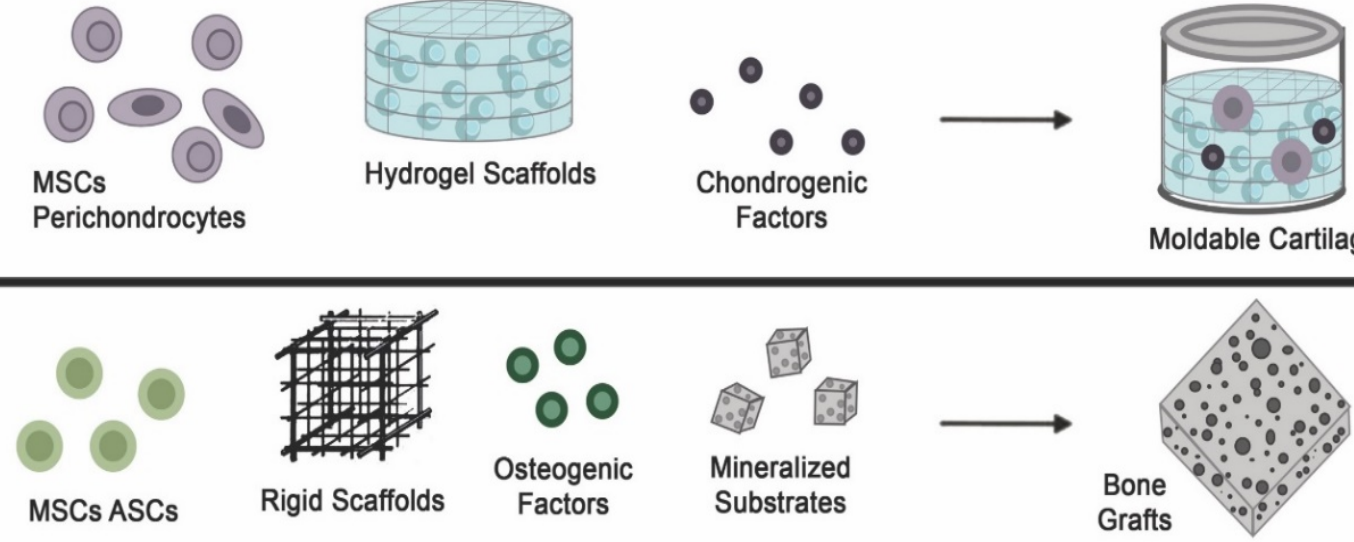

Figure 2. Strategies and Application of Tissue Engineering ${ }^{1}$ Varies stem cells are used in combination with scaffolds and additional inducing factors to engineer type specific tissue. (First row) epidermal stem cells and mesenchymal stem cells (MSCs) are seeded into epidermal or dermal scaffolds with adding growth factors to create composite skin graft, possibly used for chronic wounds reconstruction. (Second row) adipocyte gained from lipoaspirate / adipose-derived stem cells (ASCs) seeded into contoured scaffolds with added adipogenic and endothelial factors to form fat grafts customizable for soft tissue reconstruction. (Third row) MSCs and perichondrocytes seeded into hydrogel scaffolds with added chondrogenic factors to create cartilage which is moldable for cartilage-based craniofacial or other skeletal reconstruction. (Fourth row) MSCs and ASCs seeded into rigid scaffolds added with mineral and osteogenic factors to form bone grafts, useful for bone reconstruction on trauma, congenital, or tumor cases.

thickness burns. ${ }^{13}$ Two other meta-analysis analyzing efficacy of skin substitutes were unable to form conclusion due to multiple studies with small number of samples. ${ }^{14,15}$ Some centers have adapted usage of skin substitutes regularly in their practice and reported case series of 127 skin defects treated with acellular skin substitutes with etiologies ranging from difficult to heal wounds, post-excision of skin tumors, to surgical revision of contractures and scars. ${ }^{16}$
Cellular/natural skin substitutes are differed from its source into allogenic and autologous. Cellular autologous skin substitutes than further divided into cultured epithelial autografts (CEA) and cultured skin substitutes (CSS). CEA, as mentioned before, has been produced since the 1970s and usually consists of keratinocytes from patients' skin biopsy that combined with a carrier to be implanted into patients' skin defects. Meanwhile, CSS is an autologous product with a proper epidermis- 
dermis junction. This results in a more stable implantation process compared to CEA, since its epidermis-dermis junction is underdeveloped. The fragility of CEA often results in blisters upon frictions, worse hyperkeratosis, scarring, and contracture during the healing process. CSS itself presents with downfall, which is longer process time and expensive. ${ }^{11}$

Previously conducted case series in our center utilized MSCs cultured from human bone marrow and umbilical cord on 3 severe burns patients and was concluded to have positive effects in improving wound healing in severe burns patients. This study also suggested combination therapy between stem cell therapy and gene delivery for treating acute and chronic non-healing wounds. ${ }^{17}$

\section{FAT TISSUE ENGINEERING}

Fat or adipocytes are popular for their relevance to the current emerging diseases (obesity, diabetes, and other metabolic diseases). Tissue resorption and contracture/rupture are among the most common complications in adipose manipulation that is hoped to be solved by tissue engineering strategy. Adipocytes are harvested lipoaspirates before cultured on suitable contoured scaffolds to create threedimensional form and volume. Earlier development has shown volume retention in engineered fat tissue in polyethylene glycolbased hydrogel scaffold for up to four weeks following implantation, enlighting to problem of volume and shape loss following engraftment.1,5,18 A case report on expanded adipose tissue-derived mesenchymal stem cells (ASCs) showed minimal decrease in soft tissue thickness (44 mm to $42 \mathrm{~mm}$ ) 6 months' post engraftment. ${ }^{17} \mathrm{Up}$ to now, no higher level studies have confirmed adipocyte tissue engineering potential compared to conventional fat grafting for soft tissue reconstruction. 5,19

\section{CARTILAGE TISSUE ENGINEERING}

Cartilage is unique and different for its avascular characteristic of chondrocytes that resulting in suboptimal healing and poor selfrepair ability. 1,5,7 Mesenchymal stem cells and perichondrocytes are used as progenitor cells that are to be constructed on the scaffold. A report of using engineered neocartilage as a treatment of microtia in four patients shows no evidence of absorption during two and five years follow- up. ${ }^{1}$ Other study using mesenchymal progenitor cells cocultured with differentiated chondrocytes showed better result due to direction provided by mature chondrocytes in directing more normal phenotype. ${ }^{20}$ Various researches aiming to find most suitable method in subtracting and delivering chondrocytes, either expanded or nonexpanded, are still on going and not yet concluded. Complex mechanism due to cartilage's unique characteristic has yet to be explored in different methods and indications. Nevertheless, cartilage tissue engineering has been much developed and holds some potencies. ${ }^{8}$

\section{BONE TISSUE ENGINEERING}

Musculoskeletal injuries often present with significant mortality, morbidity, and socioeconomic issues, especially in such with large volume bone loss. In these cases, often autologous bone graft or bone transfer are not favored. For the past decade, bone tissue engineering has been numerously studied to address bone injuries without donor side morbidity while generating acceptable functional and mechanical properties of the constructed tissue.5,21 Osteogenic cells seeded into osteoconductive scaffold, with or without osteoinductive agent. Study done by Dilogo and colleagues used MSCs cultured with hydroxyapatite (HA) scaffold and bone morphogenetic protein (BMP-2) acting as osteoinductive ligand. The study showed significant improvement in clinical functional outcome and healing assessed radiologically on one-year follow-up with no immunologic nor neoplastic side effects. ${ }^{21}$ The comparison between bone tissue engineering method with conventional bone autograft was previously researched on randomized trial with the result favoring tissue engineered group. ${ }^{22}$

\section{CONCLUSION}

Not to counter conventional treatments that are proven to be highly successful, it is unavoidable to agree that nowadays we are faced with an increasing number of difficult cases. Increasing demand for tissue and organ (skin, bone, cartilage, fat) replacements with various accompanying comorbid that are difficult to treat, aggravated by high treatment expenses and long hospital stays, seeks for a promising solution. 
Combinations of tissue engineering with recent technologies are consistently accounted for a promising answer for medical reconstruction in recent years. Optimized strategies focusing on isolated cell sources and cultivating technology, materials suitable for scaffolds, in adjuncts with specific growth-inducing factors for each specific tissue or organ built is the key for successful tissue engineering in medical reconstruction in recent years. This being said, tissue engineering is not without challenges. Further understanding on stem cells behavior especially its characterization to specific cell types, creation of the proper microenvironment (including added natural or synthetic factors into the suitable scaffold) needed for the engineered tissue ex vivo until implanted onto the target tissue/organ along with its method of creation, and stabilization of engineered products after implantation including dressings and education to patients.

\section{ACKNOWLEDGEMENT}

Thank you to Geoffrey C. Gurtner, MD, FACS for giving permission on adapting figures from his paper and to Helena Manikya Fajar Putri, S.H. for providing adapted illustrations.

Correspondence regarding this article should be addressed to:

Michelle valeria, MD. Faculty of Medicine, Universitas Indonesia, Jakarta 12310, Indonesia.

E-Mail: mcgllvaleria@gmail.com

\section{REFERENCES}

1. Wong W.V., Rustad K.C., Longaker M.T., Gurtner G.C. Tissue engineering in plastic surgery: A review. Plast Reconstr Surg. 2010; 126:858-68.

2. Horch R.E. New developments and trends in tissue engineering: An update. J Tissue Sci Eng. 2012;3(2):110-4.

3. Sterodimas A, Faria J.D., Correa W.E., Pitanguy I. Tissue engineering in plastic surgery; An up-to-date review of the current literature. Ann Plast Surg. 2009; 62:97-103.

4. Varkey M., Ding J., Tredget E.T. Advances in skin substitutes: Potential of tissue engineered skin for facilitating anti-fibrotic healing. J Funct Biomater. 2015;6(3):547-63.

5. Treiser M.D., Austen W.G. Concepts of tissue engineering. In: Chung K.C. Grabb and smith's plastic surgery. $8^{\text {th }}$ ed. Philadelphia: Wolters Kluwer; 2020:112-8.

6. Meyer U. The history of tissue engineering and regenerative medicine in perspective. In: Meyer U., Handschel J., Wiesmann H., Meyer T. Fundamentals of tissue engineering and regenerative medicine. Berlin: Springer; 2009:512.

7. Berthiaume F., Maguire T.J., Yarmush M.L. Tissue engineering and regenerative medicine: History, progress, and challenges. Annu. Rev. Chem. Biomol. Eng. 2011; 2:40330.

8. Kementerian Kesehatan Republik Indonesia. Stem cell tak bebas dijualbelikan. Available at:

https:/ / www.kemkes.go.id/article/view/2 0011700001/stem-cell-tak-bebas-

dijualbelikan.html. Accessed April 8, 2020.

9. Future Medicine Unitec House. Sptolight on the shortlist: Ismail H. Dilogo's lab, Universitas Indonesia. Available at: https://www.regmednet.com/users/3641regmednet/posts/21082-spotlight-on-theshortlist-ismail-h-dilogo-s-lab-universitasindonesia. Accessed: April 8, 2020.

10. Dhamasana A., Singh S., Kadian S., Singh L. Skin tissue engineering: Principles and advances. J Dermatol Skin. 2018;1(1):1-11.

11. Vig K., Chaudhari A., Tripathi S. Dixit S., Sahu R., Pillai S., Dennis V.A., Singh S.R. Advances in skin regeneration using tissue engineering. Int J Mol Sci. 2017;18(4):789.

12. Chouhan D., Dey N., Bhardwaj N., Mandal B. Emerging and innovative approaches for wound healing and skin regeneration: Current status and advances. Biomaterials. 2019; 216:119267.

13. Vloemans A.F., Hermans M.H., van der Wal M.B., Liebregts J., Middelkoop E. Optimal treatment of partial thickness burns in children: A systematic review. Burns [Internet]. 2013 [cited 2020 Apr 6]. Available from:

http:/ / dx.doi.org/10.1016/j.burns.2013.09.0 16

14. Pham C., Greenwood J., Cleland H., Woodruff P., Maddern G. Bioengineered skin substitutes for management of burns: A systematic review. Burns. 2007; 33:946-57.

15. Hoogewerf C.J., Van Baar M.E., Hop M.J., Nieuwenhuis M.J., Oen I.M., Middelkoop E. Topical treatment for facial burns. Cochrane database of systematic reviews. 2013;1:CD008058. 
16. Nicoletti G., Tresoldi M.M., Malovini A., Visaggio M., Faga A., Scevola S. Versatile use of dermal substitutes: A retrospective survey of 127 consecutive cases. Indian J Plast Surg. 2018;51(1):46-53.

17. Wardhana A., Liem I.K., Feroniasanti L., Pudjiti D.J., Mujadid F., Kispa T., Novialdi. Application of allo mesenchymal stem cells on chronic burn wound: Case series report. J Plast Rekons. 2017;4(1):68-72.

18. Stosich M.S., Mao J.J. Adipose tissue engineering from human adult stem cells: Clinical implications in plastic and reconstructive surgery. Plast Reconstr Surg. 2007;119(1):71-85.

19. Bashir M.M., Sohail M., Bashil A., Khan F.A., Jan S.N., Imran M., Ahmad F.J., Choudhery M.S. Outcome of conventional adipose tissue grafting for contour deformities of face and role of ex vivo expanded adipose tissuederived stem cells in treatment of such deformities. J Craniofac Surg. 2018;29(5):1143-7.
20. Bigdeli N., Karlsson C., Strehl R., Concaro S., Hyllner J., Lindahl A. Coculture of human embryonic stem cells and human articular chondrocytes results in significantly altered phenotype and improved chondrogenic differentiation. Stem Cells. 2009;27:1812-21.

21. Dilogo I.H., Phedy P., Kholinne E., Djaja Y.P., Fiolin J., Kusnadi Y., Yulisa N.D. Autologous mesenchymal stem cell implantation, hydroxyapatite, bone morphogenetic protein-2, and internal fixation for treating critical-sized defects: a translational study. Int Orthop. 2019;43(6):1509-19.

22. Ismail H.D., Phedy, Kholinne E., Jusuf A.A., Yulisa N.D. Role of allogenic mesenchymal stem cells in the reconstruction of bone defects in rabbits. Med J Indones. 2014;23(1):9-14. 